\title{
KEMAMPUAN MENULIS PARAGRAF DESKRIPSI MENGGUNAKAN TEKNIK OBJEK LANGSUNG OLEH SISWA KELAS VII MADRASAH TSANAWIYAH NURUL FURQOON BINJAI KECAMATAN BINJAI BARAT TAHUN PELAJARAN 2018/2019
}

\author{
Juwita Erdaini, Sri Andayani \\ STKIP Budidaya Binjai
}

\begin{abstract}
Abstrak
Tujuan penelitian ini adalah untuk mengetahui "kemampuan menulis paragraf deskripsi menggunakan teknik objek langsung oleh siswa kelas VII Madrasah Tsanawiyah Nurul Furqoon Binjai Kecamatan Binjai Barat Tahun Pelajaran 2018/2019”. Metode penelitian ini menggunakan metode deskriptif kuantitatif. Kemampuan siswa dalam menentukan jenis isi presentase nilai $37,5 \%$ organisasi karagan $21,04 \%$ penggunaan bahasa $16,45 \%$ kosakata $12,5 \%$ EYD $12,5 \%$. Dengan demikian tingkat penguasaan siswa dalam menulis paragraf deskripsi menggunkan teknik objek langsung memilik presentase sebesar $99.99 \%$.
\end{abstract}

Kata Kunci : menulis, paragraf deskripsi, teknik objek langsung

\section{PENDAHULUAN}

Salah satu pengajaran bahasa Indonesia secara umum adalah agar siswa memiliki disiplin dalam berpikir dan berbahasa. Kebiasaan seseorang berpikir logis akan sangat membantu dalam pengajaran bahasa. Dalam pengajaran bahasa dikenal adanya empat keterampilan berbahasa yang perlu dicapai siswa, yaitu keterampilan mendengarkan, keterampilan berbicara, keterampilan membaca, dan keterampilan menulis. Keempat keterampilan tersebut saling berhubungan dan tidak boleh dipisah-pisahkan. Keterampilan berbicara dan keterampilan menulis merupakan keterampilan produktif, artinya siswa diharapkan mempunyai keterampilan dan kemampuan mengungkapkan gagasan menggunakan bahasa lisan maupun bahasa tulisan.

Permasalahan pendidikan selalu muncul bersamaan dengan berkembang dan meningkatnya kemampuan siswa, situasi dan kondisi lingkungan yang ada, pengaruh informasi dan kebudayaan, serta berkembangnya ilmu pengetahuan dan teknologi. Pada hakikatnya, pembelajaran bahasa adalah belajar berkomunikasi, mengingat bahasa merupakan sarana komunikasi dalam masyarakat. Untuk berkomunikasi dengan baik, seseorang perlu belajar cara berbahasa yang baik dan benar. Pembelajaran tersebut akan lebih baik manakala dipelajari sejak dini dan berkesinambungan. Oleh karena itu, 


\section{Jurnal Serunai Ilmu Pendidikan \\ Vol.4, No.1, Desember 2018 \\ e-ISSN 2621-2676}

pembelajaran bahasa disertakan dalam kurikulum. Hal ini berarti setiap siswa dituntut untuk mampu menguasai bahasa yang mereka pelajari terutama bahasa resmi yang dipakai oleh Negara yang ditempati siswa.

Begitu pula, bahasa Indonesia menjadi materi pembelajaran yang wajib diberikan di setiap jenjang pendidikan, mulai dari sekolah dasar sampai perguruan tinggi. Hal itu dilakukan supaya siswa mampu menguasai bahasa Indonesia dengan baik dan benar serta mampu menerapkannya dalam kehidupan masyarakat. Dalam hubungannya dengan pengajaran bahasa, Dalam Dalman (2015:4) Tarigan menyatakan bahwa menulis adalah menurunkan atau melukiskan lambang-lambang grafik yang menggambarkan suatu bahasa yang dipahami oleh seseorang, sehingga orang lain dapat membaca lambang-lambang grafik tersebut kalau mereka memahami bahasa dan grafik itu.

Sejalan dengan pendapat di atas, Sukirno (2010:4) juga menyatakan bahwa tujuan menulis yaitu memberikan informasi kepada orang lain atau pembaca, menceritakan suatu peristiwa, melaporkan sesuatu, mengisahkan kejadian, melukiskan tindak-tanduk manusia dalam sebuah persitiwa yang menimbulkan daya khayal/ imajinasi pembacanya, dan menarik suatu makna baru di luar apa yang diungkapka secara tersurat.

Kemampuan menulis merupakan upaya untuk mengungkapkan segala sesesuatu yang terdapat dalam konsep pemikiran ke dalam bentuk bahasa tulis atau tulisan. Kemampuan menulis perlu diperhatikan karena merupakan salah satu keterampilan berbahasa yang harus dimiliki oleh siswa. Dengan menulis, siswa dapat mengungkapkan atau mengekspresikan gagasan atau pendapat, pemikiran, dan perasaan yang dimiliki. Selain itu, siswa dapat mengembangkan daya pikir dan kreativitas dalam menulis. Menulis sebagai suatu keterampilan berbahasa yang dipergunakan untuk berkomunikasi secara langsung.

Dalam Kurikulum Tingkat Satuan Pendidikan ditegaskan bahwa tugas sebagai guru adalah membelajarkan siswa, bukan mengajar. Siswalah yang harus didorong agar aktif berlatih menggunakan bahasa pada kemampuan menulis. Standar kompetensi bahasa Indonesia yang merupakan kualifikasi kemampuan minimal siswa yang menggambarkan penguasaan pengetahuan, keterampilan berbahasa, dan sikap positif terhadap bahasa Indonesia. Selain itu, standar kompetensi adalah dasar bagi siswa untuk dapat memahami dan mengakses perkembangan lokal, regional, dan global. Dalam Dalman (2015:94), 


\section{Jurnal Serunai Ilmu Pendidikan \\ Vol.4, No.1, Desember 2018 \\ e-ISSN 2621-2676}

Suparno dan Yunus menyampaikan deskripsi adalah suatu bentuk paragraf yang melukiskan sesuatu sesuai dengan keadaan sebenarnya, sehingga pembaca dapat mencitrai (melihat, mendengarkan, mencium dan merasakan) apa yang di lukiskan itu sesuai dengan citra penulisnya.

Deskripsi memberi satu citra mental mengenai sesuatu hal yang dialami, misalnya pemandangan, orang atau sensasi. Fungsi utama dari deskripsi adalah membuat para pembacanya melihat barang-barang atau objeknya, atau menyerap kualitas khas dari barang-barang itu. Deskripsi membuat pembaca melihat yaitu membuat visualisasi mengenai objeknya, atau dengan kata lain deskripsi memusatkan uraiannya pada penampakan barang. Suyatno (2004:82) menyampaikan Dalam deskripsi terdapat objek garapan secara hidup dan konkret, objek secara bulat. Suyatno menyatakan bahwa teknik pembelajaran menulis langsung bertujuan agar siswa dapat menulis dengan cepat berdasarkan objek yang diteliti.

Objek yang ditunjukkan objek kepada siswa di depan kelas, yaitu ruangan kelas VII A. Dari objek tersebut siswa dapat membuat tulisan secara runtut dan logis berdasarkan objek yang dilihatnya. Teknik ini dapat dijalankan secara perseorangan maupun secara kelompok. Ini yang dibahas tentang kemampuan menulis khususnya menulis paragraf deskripsi. Berdasarkan hasil observasi, kemampuan siswa untuk menulis masih sangat terbatas, terlebih lagi untuk dapat menulis paragraf deskripsi mereka kesulitan untuk membedakan jenis-jenis paragraf. Agar siswa dapat menulis dengan baik, siswa perlu dipacu dengan menggunakan teknik dan media yang menarik. Untuk itu, perlu mencari upaya yang dapat membuat siswa tertarik dan agar siswa dapat menulis dengan baik. Dalam menulis paragraf deskripsi dibutuhkan ketelitian, kepaduan, keruntutan, dan kelogisan antara kalimat satu dengan kalimat yang lain, antara paragraf dengan paragraf berikutnya sehingga akan membentuk sebuah karangan yang baik dan utuh.

Pengajaran menulis, khususnya menulis paragraf deskripsi adalah kemampuan yang bertujuan untuk mengajukan suatu objek atau suatu hal yang sedemikian rupa, sehingga objek itu berada di depan kepala pembaca. Menurut hasil observasi yang dilakukan pada kelas VII Madrasah Tsanawiyah Nurul Furqoon Binjai Kecamatan Binjai Barat, menentukan berbagai masalah yang muncul sebagai akibat dari rendahnya kemampuan menulis siswa. Sesuai dengan kondisi di lapangan bahwa, berbagai masalah 
itu antara lain berkaitan alokasi waktu pembelajaran menulis yang lebih sedikit dibandingkan dengan alokasi waktu keterampilan berbahasa yang lain.

Selain itu, siswa merasa belum mampu menyusun kalimat dengan struktur kalimat, bahasa yang baik dan benar. Keadaan ini mengakibatkan tidak efektifnya pembelajaran menulis di kelas. Kemampuan menulis paragraf deskripsi menggunakan teknik objek langsung oleh siswa kelas VII Madrasah Tsanawiyah Nurul Furqoon Binjai Kecamatan Binjai Barat, masih sangat rendah. Setelah diamati dengan seksama ketidakberhasilan itu terjadi karena beberapa faktor. Faktor-faktor yang mengakibatkan rendahnya kemampuan menulis paragraf deskripsi di Madrasah Tsanawiyah Nurul Furqoon Binjai Kecamatan Binjai Barat, antara lain karena siswa kurang memahami tentang hakikat paragraf deskripsi yang sebenarnya, siswa kurang memperhatikan dan menganggap mudah pokok bahasan ini dan jarangnya menggunakan media pembelajaran sebagai media penyampaian materi pada siswa, pada umumnya jarang menggunakan media pembelajaran pada saat penyampaian materi, sehingga para siswa menjadi cepat jenuh dan semakin tidak berminat untuk menulis, dan banyak siswa beranggapan bahwa keterampilan menulis itu adalah keterampilan yang paling sulit karena mereka sulit untuk mengawali kalimat dalam sebuah paragraf.

Selain itu, setelah melakukan observasi langsung ke sekolah, bahwa jarang menggunakan media atau teknik pembelajaran, sehingga siswa merasa jenuh dan bosan karena pembelajaran yang diberikan kurang menarik dan bersifat monoton. Dari berbagai faktor dan kenyataan seperti itu, masih dapat diatasi harus sering memberikan bimbingan, latihan, dan motivasi pada siswa untuk menulis, sehingga siswa dapat menuangkan ide atau gagasan dalam bentuk tulisan dengan baik. Bimbingan yang diberikan kepada siswa adalah bimbingan secara intensif atau secara sungguh-sungguh dan terus menerus sehingga memperoleh hasil yang optimal. Melalui penelitian ini, akan mencoba satu pembaharuan untuk meningkatkan kemampuan menulis paragraf deskripsi mengnggunakan teknik objek langsung. Menggunakan teknik objek langsung ini sebagai pembelajaran menulis paragraf deskripsi sehingga diharapkan siswa akan lebih tertarik untuk menuangkan ide atau gagasan dalam bentuk tulisan dan diharapkan dapat mengurangi kejenuhan siswa dalam pembelajaran menulis. Rumusan masalah dalam penelitian ini adalah bagaimana kemampuan menulis paragraf deskripsi menggunakan teknik objek langsung oleh siswa 
kelas VII Madrasah Tsanawiyah Nurul Furqoon Binjai Kecamatan Binjai Barat Tahun Pelajaran 2018/2019?

\section{METODE}

Penelitian ini dilakukan pada siswa kelas VII Madrasah Tsanawiyah Nurul Furqoon Binjai Kecamatan Binjai Barat Tahun Pelajaran 2018/2019, yang berada di Jalan Jendral Gatot Subroto No. 147 Binjai, Kelurahan Bandar Senembah, Kecamatan Binjai Barat. Adapun waktu penelitian ini dilaksanakan pada semester ganjil tahun pembelajaran $2018 / 2019$.

Sasaran penelitian ini adalah siswa kelas VII Madrasah Tsnawiyah Nurul Furqoon Binjai Kecamatan Binjai Barat yang berjumlah 120 siswa. Berarti 120 X 25\% / $100=30$, jadi sampel yang digunakan dalam penelitian ini sebanyak 30 siswa.

Metode penelitian ini menggunakan metode deskriptif kuantitatif. Dalam penelitian ini instrumen yang digunakan ialah tes essai. Hasil paragraf deskripsi inilah yang akan diberi nilai. Bobot nilai yang diberikan didasari atas kemampuan siswa dalam menulis paragraf deskripsi menggunkan teknik objek langsung. Nilai yang nantinya diperoleh setiap siswa akan dapat menunjukan seberapa besar kemampuan mereka dalam menulis paragraf deskripsi menggunkan teknik objek langsung.

Suparno dan Yunus (2006:135) menyampaikan untuk menganalisis data yang diperoleh penulis menempuh langkah-langkah sebagai berikut :

1. Menghitung hasil kemampuan siswa

2. Menghitung nilai akhir setiap siswa, dengan menggunakan rumus angka mutlak, yaitu : tingkat penguasaan $=$ Jumlah skor perolehan x $100 \%$

Jumlah skor maksimal

3. Menghitung mean dan nilai rata-rata siswa :

Jumlah nilai keseluruhan

$$
\mathrm{M}=
$$

Jumlah siswa

4. Membandingkan nilai rata-rata dengan patokan nilai yang dikemukakan oleh Suparno dan M, Yunus :

Arti tingkat penguasaan : $90-100 \%=$ baik sekali 


$$
\begin{aligned}
80-89 \% & =\text { baik } \\
70-79 \% & =\text { cukup } \\
<70 \% & =\text { kurang }
\end{aligned}
$$

Teknik pengumpulan data dalam penelitian ini menggunakan teknik tes. Teknik tes digunakan untuk mengetahui kemampuan siswa dalam menulis paragraf deskripsi.

\section{HASIL PENELITIAN DAN PEMBAHASAN}

Kemampuan siswa dalam menentukan jenis isi presentase nilai 37,5\% organisasi karagan 21,04\% penggunaan bahasa 16,45\% kosakata 12,5\% EYD 12,5\%. Dengan demikian tingkat penguasaan siswa dalam menulis paragraf deskripsi menggunkan teknik objek langsung memilik presentase sebesar $99.99 \%$.

Bila kita merajuk pada pendapat Suparno dan M. Yunus (2006: 135) arti tingkat penguasaan : $90-100 \%$

$$
\begin{array}{r}
80-89 \% \\
70-79 \% \\
<70 \%
\end{array}
$$

Maka kemampuan menulis paragraf deskripsi menggunakan teknik objek langsung oleh siswa kelas VII Madrasah Tsanawiyah Nurul Furqoon Binjai Kecamatan Binjai Barat Tahun Pelajaran 2018/2019, dengan skor presentase tingkat penguasaan sebesar 99,99\% dikatagorikan baik sekali. Untuk lebih jelasnya lagi mengenai presentase yang diperoleh siswa dari aspek-aspek yang dinilai dalam menulis paragraf deskripsi menggunakan teknik objek langsung oleh siswa kelas VII Madrasah Tsanawiyah Nurul Furqoon Binjai Kecamatan Binjai Barat Tahun Pelajaran 2018/2019 dapat kita lihat pada histogram berikut ini:

\section{Histogram Kemampuan Menulis Paragraf Deskripsi Menggunakan Teknik Objek Langsung oleh Siswa Kelas VII SMP Madrasah Tsanawiyah Nurul Furqoon Binjai Kecamatan Binjai Barat Tahun Pelajaran 2018/2019}




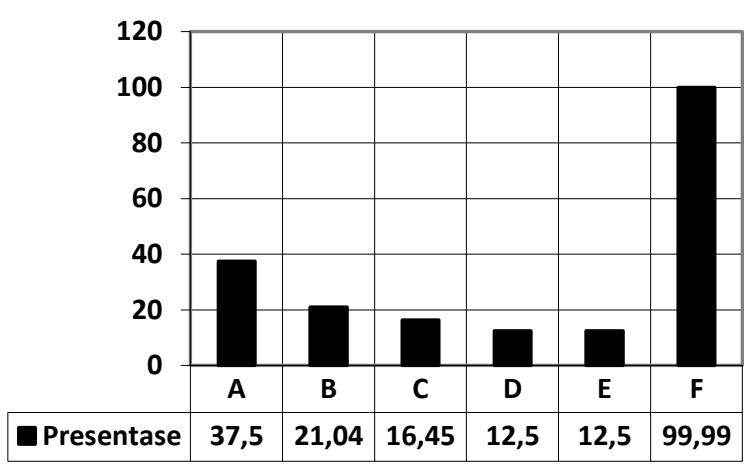
A. Kemampuan Menulis Isi
B. Organisasi Karangan
C. Kemampuan Penggunaan Bahasa
D. Ketepatan Kosa kata
E. Penggunaan EYD
F. Tingkat Penguasaan Siswa

Menghitung mean rata-rata kemampuan menulis paragraf deskripsi menggunakan teknik objek langsung oleh siswa kelas VII Madrasah Tsanawiyah Nurul Furqoon Binjai Kecamatan Binjai Barat Tahun Pelajaran 2018/2019 dengan menggunakan rumus :

$$
\begin{aligned}
& \mathrm{M}=\frac{\text { Jumlah }- \text { Nilai }- \text { Keseluruhan }}{\text { Jumlah }- \text { Siswa }} \\
& \mathrm{M}=\frac{2400}{30} \\
& \mathrm{M}=80
\end{aligned}
$$

Berdasarkan perhitungan di atas dapat diketahui nilai rata-rata kemampuan menulis paragraf deskripsi menggunakan teknik objek langsung oleh siswa kelas VII Madrasah Tsanawiyah Nurul Furqoon Binjai Kecamatan Binjai Barat Tahun Pelajaran 2018/2019 adalah 80 masuk dalam kategori baik.

Selanjutnya kita akan mempresentasekan jumlah masing-masing siswa yang mampu dalam menulis kemampuan menulis paragraf deskripsi menggunakan teknik objek langsung oleh siswa kelas VII Madrasah Tsanawiyah Nurul Furqoon Binjai Kecamatan Binjai Barat Tahun Pelajaran 2018/2019 pada setiap perangkat nilai. Seberapa banyak 
siswa yang mampu menulis dengan katagori, baik sekali, baik, cukup, dan kurang. Masingmasing akan kita presentasikan dari jumlah siswa yang termasuk dalam katagori tersebut dibagi dengan total seluruh sample penelitian dan dikali seratus persen.

\section{SIMPULAN}

1. Kemampuan menulis paragraf deskripsi menggunakan teknik objek langsung oleh siswa kelas VII Madrasah Tsanawiyah Nurul Furqoon Binjai Kecamatan Binjai Barat Tahun Pelajaran 2018/2019 dapat dikatagorikan cukup, dengan nilai rata-rata 80.

2. Sedangkan tingkat presentasi masing-masing siswa dalam setiap aspek sangat memuaskan.

\section{REFERENSI}

Dalman. Keterampilan Menulis. Jakarta: PT Raja GrafindoPersada. 2005.

Suyatno. Teknik Pembelajaran Bahasa dan Sastra. Surabaya: Penerbit SIC. 2004.

Sukirno. Pembelajaran Menulis Kreatif dengan Strategi Belajar Akselerasi Purworejo : UM Purworejo Press. 2009.

Suparno dan Yunus, M. Keterampilan Dasar Menulis. Jakarta: Gramedia. 2006. 